\section{A) Check for updates}

Cite this: Food Funct., 2020, 11, 358

\title{
Lysine blockage of milk proteins in infant formula impairs overall protein digestibility and peptide release
}

\author{
Hannah E. Zenker, (D) $\dagger^{\mathrm{a}}$ Glenn A. A. van Lieshout, (D) $\dagger^{\mathrm{b}}$ Martine P. van Gool, ${ }^{\mathrm{b}}$ \\ Marjolijn C. E. Bragt ${ }^{b}$ and Kasper A. Hettinga*a
}

\begin{abstract}
During heat processing of milk and dairy products, for example infant formula, the Maillard reaction occurs. In vitro and animal studies suggest that Maillard reaction induced lysine blockage impairs protein digestibility. Most studies that investigate the effect of glycation on protein digestion use a mixture of isolated milk protein with reducing sugars. In this study, infant formulas with $6.5 \%, 8.4 \%, 11.2 \%, 14.8 \%, 20.8 \%$, and $44.5 \%$ of blocked lysine (BL) were digested in an in vitro infant digestion model and tested for protein hydrolysis and peptide release. OPA (o-phthalaldehyde) assay was used to assess the degree of protein hydrolysis. SDS-PAGE was conducted to monitor the hydrolysis of specific proteins. Peptides formed after gastric and intestinal digestion were identified by LC/MS. Protein hydrolysis of the $6.5 \%$ BL sample was significantly higher after 10 minutes of intestinal digestion compared to all other samples. Most differences were observed after intestinal digestion. A significant change in peptide patterns was observed for the $45 \% \mathrm{BL}$ sample resulting in a relatively higher number of peptides with more than 14 amino acids. Mainly casein-derived peptides were affected. Overall, the average peptide length was significantly increased for the $44.5 \%$ BL glycated product (on average 10.2 amino acids for 6-21\% BL vs. 11.4 amino acids for $45 \%$ $\mathrm{BL} ; \mathrm{p}$ 0.001). In conclusion, glycation of milk proteins in an infant formula product can impair overall protein digestibility. These findings emphasize the importance of mild processing and having low $\mathrm{BL}$ levels in infant formula to ensure optimal digestion of proteins.
\end{abstract}

Received 9th September 2019, Accepted 12th November 2019 DOI: $10.1039 /$ c9fo02097g rsc.li/food-function
The effect of heat treatment on milk protein digestibility reported in the literature is still controversial and strongly depends on the protein modifications that occurred during thermal processing. However, most in vitro and animal studies on (isolated) milk proteins that focus more specifically on the effect of glycation suggest that lysine blockage impairs protein digestibility. ${ }^{4}$ True ideal digestibility of lysine and other amino acids was reduced in rats when feeding a heated mixture of lactic casein or skimmed milk powder with lactose compared to when feeding a non-heated mixture. ${ }^{5,6}$ Furthermore, a study in pigs demonstrates that $50 \%$ blockage of lysine in skimmed milk powder results in a significant decrease in post-prandial plasma appearance of lysine and total amino acids. ${ }^{7}$ This is in line with most in vitro digestion studies that measured protein hydrolysis during or after simulated gastrointestinal digestion (by OPA-assay, SDS-PAGE or peptide formation) and they show decreased hydrolysis of milk proteins when heated with a reducing sugar. ${ }^{8,9-14}$

Three possible mechanisms are suggested to be involved in this decreased digestibility. First, glycation of lysine residues can protect them from recognition by proteases that cleave after a lysine residue, e.g. trypsin, resulting in direct blockage

\footnotetext{
${ }^{a}$ Food Quality \& Design Group, Wageningen University \& Research Centre, Wageningen, the Netherlands. E-mail: kasper.hettinga@wur.nl

${ }^{b}$ FrieslandCampina, Amersfoort, the Netherlands

$\dagger$ These authors contributed equally to this work.
} 
of the cleavage site. ${ }^{10,11,15,16}$ Second, glycation can indirectly block the cleavage site by glycation of lysine residues that are positioned near the cleavage site, within the docking area of an enzyme. ${ }^{16}$ Lastly, glycation-induced cross-linking of lysine with other amino acids can decrease the accessibility of cleavage sites for proteases. ${ }^{15}$ As well as the decreased digestibility of glycated proteins, increased digestibility has also been observed after heating of whey protein isolate and $\alpha$-lactalbumin, possibly due to the unfolding of the globular whey proteins as a result of heating, making hidden cleavage sites better accessible. ${ }^{17-19}$ Wada and Lönnerdal ${ }^{20}$ showed that milk protein digestibility increased with the intensity of 'industrial' heat treatments of milk. However, these 'industrial' heat treatments of milk led to protein modifications other than lysine blockage only. These contradictory findings on digestibility suggest that a balance between protein unfolding and steric hindrance after heat treatment determines whether an increase or decrease in digestibility is found.

Although quite some research has been performed on the effect of industrial heat treatment and glycation on the digestion of milk and infant formula, research on the direct effect of blocked lysine only on the digestion of infant formula is limited. The high contents of lactose and lysine together with a neutral $\mathrm{pH}$ make the proteins in infant formula susceptible to glycation. ${ }^{3,21}$ The EFSA panel on dietetic products, nutrition and allergies (NDA) states that the content of Maillard reaction products in infant formula should be limited as much as possible to preserve the nutritional quality of proteins. ${ }^{22}$ Since infant formula is the only source of protein when infants are not breastfed, it is of major importance that the protein is of high nutritional quality. BL percentages in infant formula, including powdered and liquid infant formula products, range between 8 and $55 \%$, but most studies report a range between 5 and $34 \% .^{3}$ One study showed that apparent digestibility in rats was lower for sterilized infant formula products compared to powdered products, while another study showed decreased in vitro hydrolysis for liquid infant formula model systems heated with lactose or maltodextrin compared to heating without carbohydrates. ${ }^{19,23}$ In another study, Rudloff and Lönnerdal ${ }^{24}$ compared the protein digestibility of commercial infant formulas with different heat treatments, but the variety of heat-induced modifications does not allow a conclusion on the effect of glycation only. No studies are found that compare the same powdered infant formula products at different glycation levels. In this study, powdered infant formulae with different levels of BL were digested in an in vitro infant digestion model. To minimize the effect of protein unfolding on digestibility, heating was carried out in a dry state and at low temperatures $\left(60^{\circ} \mathrm{C}\right.$ and $\left.70^{\circ} \mathrm{C}\right)$. A recently proposed model for in vitro simulation of full-term infant digestion was used. ${ }^{25}$ Protein hydrolysis is assessed by measuring the degree of hydrolysis, disappearance of intact proteins and peptide formation. The hypothesis is that an increased lysine blockage impairs the overall protein digestibility in infant formula by inhibiting the hydrolysis of intact proteins, resulting in increased peptide length after simulated gastrointestinal digestion.

\section{Materials \& methods}

\section{Chemicals}

Mark12 ${ }^{\mathrm{TM}}$ unstained standard, NuPAGE® LDS sample buffer ( $4 \times$ conc.), NuPAGE ${ }^{\circledR}$ Sample Reducing Agent, and NuPAGE ${ }^{\mathrm{TM}}$ MES SDS Running Buffer (20×) were purchased from Thermo Fisher (Waltham, USA). Dithiothreitol, cellulose, L-leucine, and lipase were obtained from Rhizopus oryzae (Sigma 80612) and $o$-phthaldialdehyde, pefabloc SC, porcine pepsin from gastric mucosa (P700), porcine pancreatin $4 \times$ USP (P1750), sodium bicarbonate, sodium dodecyl sulfate, sodium iodide, leucine enkephalin II, and trifluoroacetic acid >99\% LC-MS grade were purchased from Sigma-Aldrich (St Louise, USA). Difco TM Oxgall (dehydrated fresh bile) was purchased from Becton, Dickinson and Company (Le Pont de Claix, France). Trichloroacetic acid, sodium hydroxide, and sodium chloride were purchased from VWR Chemicals (Radnor, USA). Disodium hydrogen phosphate dihydrate, glacial acetic acid, hydrochloric acid, and potassium chloride were obtained from Merck (Darmstadt, Germany). Methanol HPLC grade was purchased from Actu-All Chemicals (Oss, Netherlands). ULC/ MS-CC/SFC water and ULC/MS-CC/SFC acetonitrile were purchased from Biosolve (Chimie, France). D-Methionine was purchased from Acros Organics (New Jersey, USA). Sodium tetraborate decahydrate was purchased from Thermo Fisher Scientific (Waltham, USA). Coomassie Brilliant Blue R-250 was purchased from Biorad (Hercules, USA). Ultra-pure water was prepared using an ELGA LabWater Purelab Plus water system (Celle, Germany).

\section{Infant formula}

Infant formula was obtained from FrieslandCampina (FrieslandCampina, Amersfoort, the Netherlands) and composed of $11 \mathrm{~g}$ per $100 \mathrm{~g}$ protein (60:40 whey: casein ratio), $53 \mathrm{~g}$ per $100 \mathrm{~g}$ lactose and $27 \mathrm{~g}$ per $100 \mathrm{~g}$ fat. A single batch was used and divided over several jars to be incubated in a stove. The jars were completely filled to minimize the amount of air and firmly closed before incubation. Meanwhile, glycation was induced by the storage of the powdered infant formula in a stove at $60{ }^{\circ} \mathrm{C}$ for $0,1,3,7$, and 12 days and at $70{ }^{\circ} \mathrm{C}$ for 14 days to achieve BL levels of $6,8,12,15,20$ and $45 \%$.

\section{Blocked lysine}

The level of BL was calculated from lysine and furosine contents as a measure for the early Maillard reaction. Total lysine content and furosine content after acid hydrolysis were measured by ion-pair reversed-phase HPLC (Ansynth Service B. V., Breda, the Netherlands). ${ }^{26}$ In turn, the furosine content was used to calculate the level of lysine blockage in the samples. ${ }^{3}$

\section{Infant in vitro digestion}

In vitro digestion was conducted based on a protocol for 3-6 month old infants as published by Ménard et $a l^{25}$ In short, infant formula samples were diluted in demineralised water as instructed on the pack, resulting in a standardised 
protein level of $1.6 \%$. The protein content in powdered infant formula was determined using DUMAS (data not shown). The samples were heated at $37{ }^{\circ} \mathrm{C}$ for 15 minutes in a shaking water bath. An aliquot of the preheated meal was taken as a control sample prior to digestion. The gastric phase (GP) was conducting by incubation in a shaking water bath for 60 minutes at $37{ }^{\circ} \mathrm{C}$. The ratio of the meal to the simulated digestive fluid, enzyme activity, $\mathrm{pH}$ and bile salt concentration were used as described by Menard et al. However, rabbit gastric extract was replaced by Rhizopus oryzae lipase and porcine pepsin. Samples were taken every 15 minutes and enzyme activity was stopped using $10 \mu \mathrm{L}$ of $0.72 \mu \mathrm{M}$ pepstatin per $\mathrm{mL}$ digest. Gastric samples were centrifuged (4500 rcf, 5 minutes, $4{ }^{\circ} \mathrm{C}$ ) using an Eppendorf centrifuge $5430 \mathrm{R}$ (Eppendorf, Hamburg, Germany). In the intestinal phase (IP), samples were taken after 0.3 minutes, 1 minute, 3 minutes, 5 minutes, 10 minutes, 15 minutes, 30 minutes, 60 minutes and 120 minutes of intestinal digestion. Enzyme activity was stopped by adding $50 \mu \mathrm{L}$ of $0.1 \mathrm{M}$ pefabloc per $\mathrm{mL}$ sample. Digestion experiments were performed once for each sample.

\section{Gel electrophoresis}

Protein gel electrophoresis was performed on GP samples taken after $0.3,15,30,45$, and 60 minutes as well as on IP samples taken after 5, 15, 30, 60, and 120 minutes. The sample taken after 15 minutes of incubation at $37^{\circ} \mathrm{C}$ prior to digestion was taken as a control. GP digests were diluted in a ratio $4 / 5 / 11 / 2(\mathrm{v} / \mathrm{v} / \mathrm{v} / \mathrm{v})$ of the sample with NuPAGE ${ }^{\circledR}$ LDS sample buffer $4 \times$ conc., MilliQ and NuPAGE ${ }^{\circledR}$ Sample Reducing Agent. IP samples were diluted in a ratio of 6.5/5/9.5/ $2(\mathrm{v} / \mathrm{v} / \mathrm{v} / \mathrm{v})$ to achieve the same protein concentration in each gel lane. A Mark $12^{\mathrm{TM}}$ unstained molecular weight (MW) marker was used as the size standard. Ten microliters of each sample were loaded on a $4-12 \%$ bis-tris precast polyacrylamide NuPAGE, $1.0 \mathrm{~mm}$, 12-well precast protein gel (Invitrogen, Carlsbad, USA). NuPAGE MES running buffer was used to separate the proteins based on their molecular weights at $120 \mathrm{~V}$ (constant mode). Gels were stained with Coomassie Brilliant Blue R-250 staining solution and washed with 10\% $(\mathrm{v} / \mathrm{v})$ ethanol and $7.5 \%(\mathrm{v} / \mathrm{v})$ acetic acid washing solution. The images of each gel were obtained using Universal Hood III (Biorad, Hercules, USA) and Image Lab 4.1 software (Biorad, Hercules, USA).

\section{Enzymatic protein hydrolysis}

Protein hydrolysis was determined using the OPA-method on a micro-titre scale, as described elsewhere, with some modifications. $^{27}$ Briefly, prior to analysis, the samples were precipitated with $10 \%$ TCA $(0.4 \mathrm{~mL})$ to $0.5 \mathrm{~mL}$ digest. The samples were diluted to a protein ratio between 0.1 and $10 \%$ with $10 \mathrm{mM}$ PBS (137 mM NaCl, $10 \mathrm{mM}$ phosphate, and $2.7 \mathrm{mM}$ potassium chloride, $\mathrm{pH}$ of 7.4). Acidic protein hydrolysates were prepared by heating $4 \mathrm{mg}$ protein per $\mathrm{mL} 6 \mathrm{M}$ hydrochloric acid at $110{ }^{\circ} \mathrm{C}$ for 22 hours. Standard solutions of L-leucine were prepared in a concentration range of 5 to $50 \mathrm{mM}$ with $10 \mathrm{mM}$ PBS. Ten microliters of the sample and standard solution were pipetted in each well and $200 \mu \mathrm{L}$ of the OPA reagent was added. The solutions were incubated for 15 minutes at room temperature, and then the absorbance at $340 \mathrm{~nm}$ was measured using a microplate reader (TECAN, NanoQuant infinite M200 Pro, Maennedorf, Schwitzerland). Each sample was measured in triplicate.

Degree of hydrolysis (DH) was calculated using the following formula:

$$
\begin{aligned}
\mathrm{DH}= & \left(\left[\mathrm{NH}_{2}(\text { final })-\mathrm{NH}_{2}(\text { initial })\right] /\left[\mathrm{NH}_{2}(\text { acid })\right.\right. \\
& \left.\left.-\mathrm{NH}_{2}(\text { initial })\right]\right) \times 100
\end{aligned}
$$

where $\mathrm{NH}_{2}$ (final) is the concentration of the free amino groups in the digested sample, $\mathrm{NH}_{2}$ (initial) is the concentration of the free amino groups in the undigested sample (at time 0 of digestion), and $\mathrm{NH}_{2}$ (acid) is the total content of the free amino groups in the sample after acid hydrolysis.

\section{Peptidomics}

Peptides were measured in all samples prior to digestion, after 60 minutes in the GP and after 60 minutes in the IP. To reduce disulfide bridges and to facilitate peptide annotation, the samples were first incubated for 2 hours with a buffer composed of $6 \mathrm{M}$ urea, $0.5 \mathrm{M}$ Tris, and $100 \mathrm{mM}$ dithiothreitol (DTT) at pH 7.5 at a protein concentration of $0.5 \%(\mathrm{w} / \mathrm{v})$. After incubation, the samples were further diluted in eluent $\mathrm{A}$ to a final protein concentration of $0.1 \% \quad(\mathrm{w} / \mathrm{v})$, centrifuged (10 minutes, $19000 \mathrm{~g}, 20^{\circ} \mathrm{C}$ ) and filtered through a $0.2 \mu \mathrm{m} \mathrm{RC}$ syringe filter (Phenomenex, Torrance, USA).

Peptides were analysed using a Synapt G2-Si high definition mass spectrometer (Waters, Milford, USA) coupled to a Waters uHPLC-ESI-MS/MS system. The system was equipped with a z-spray electron spray ionisation (ESI) source, a PDA-detector, a hybrid quadrupole, and an orthogonal time-of-flight (Q-TOF) detector. The peptides were separated over an Acquity UPLC BEH 300 C18 column $(2.1 \times 150 \mathrm{~mm}, 1.7 \mu \mathrm{m}$ particle size $)$ with an Acquity BEH C18 Vanguard precolumn $(2.1 \times 50 \mathrm{~mm}$, $1.7 \mu \mathrm{m}$ particle size) at $40{ }^{\circ} \mathrm{C}$. Eluent A was composed of $1 \%$ $(\mathrm{v} / \mathrm{v})$ acetonitrile $(\mathrm{ACN})$ containing $0.1 \%(\mathrm{v} / \mathrm{v})$ trifluoroacetic acid (TFA) in ULC/MS-CC/SFC water and eluent B was composed of $100 \%$ ACN containing $0.1 \%(\mathrm{v} / \mathrm{v})$ TFA. The flow rate

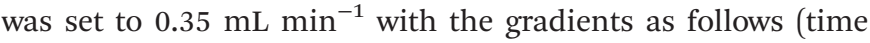
[min]/eluent A [\%]): (0/100), (5/100), (45/59.5), (46/10), (49/10), (50/100), and (56/100). An autosampler was kept at $10^{\circ} \mathrm{C}$ and $4 \mu \mathrm{L}$ of each sample was injected. A PDA detector was used to measure the absorbance between 200 and $400 \mathrm{~nm}$ at $1.2 \mathrm{~nm}$ resolution with channel 1 set to $214 \mathrm{~nm}$ and channel 2 set to $280 \mathrm{~nm}$ at a resolution $4.8 \mathrm{~nm}$. Prior to analysis, the MS was calibrated using a sodium iodide solution $\left(2 \mu \mathrm{g} \mu \mathrm{L}^{-1}\right)$ between 100 and $2000 \mathrm{~m} / \mathrm{z}$. Leucine enkephalin $\left(1 \mathrm{ng} \mu \mathrm{L}^{-1}\right)$ was used as lock mass at an infusion flow rate of $20 \mu \mathrm{L} \mathrm{min}{ }^{-1}$. The source was operated at a source temperature of $120{ }^{\circ} \mathrm{C}$ and the capillary voltage was set at $3 \mathrm{kV}$. The sample cone was set to $35 \mathrm{~V}$ and the source offset to $60 \mathrm{~V}$. Nitrogen was used as the desolvation gas $\left(250{ }^{\circ} \mathrm{C}, 800 \mathrm{~L} \mathrm{~h}^{-1}\right)$ and cone gas $\left(200 \mathrm{~L} \mathrm{~h}^{-1}\right)$. MS and MS/MS (MSe method) spectra were monitored in resolution 
mode at positive polarity. Masses were measured between $\mathrm{m} / \mathrm{z}$ 100 and 2000 using a scan time of 0.3 s. UV and MS data were acquired using MassLynx software 1.65.1929 (Waters, Milford, USA).

Chromatograms were processed with the UNIFI Scientific Information System (Waters, Milford, USA) between 2 minutes and 47.5 minutes of retention time. The match tolerance was set to $10 \mathrm{ppm}$. The maximum molecular weight of the identified peptides was $5 \mathrm{kDa}$, while the minimum peptide length used for the annotation of the peptides was 5 amino acids. Peptide cleavage was set to non-specific with variable modifications set to deamidation on asparagine and glutamine and oxidation on methionine. Lock mass correction was applied for the reference mass $556.276575 \mathrm{~m} / \mathrm{z}$ in a mass window of 0.5 $\mathrm{m} / \mathrm{z}$. For caseins all possible phosphorylation sites according to the UniProt database (https://www.uniprot.org/) were used as possible modifications. For casein- and whey proteinderived peptides, glycation was used as variable modification. Glycated peptides were identified by adding the mass difference of $n$ dehydrated hexose $(\mathrm{s})(+n \times 162 \mathrm{Da})$ to the mass of the original peptide.

Two separate identification runs were performed for whey protein and casein proteins after which the data were grouped and duplicate identifications were filtered. In the case of a double annotation for a peptide, the annotation with the highest number of identified $\mathrm{b} / \mathrm{y}$ ions was selected as the most likely identification. When the number of identified b/y-ions was equal, mass accuracy was considered where the peptide with a higher mass accuracy was selected. When the mass accuracy was equal, the peptide with the highest assigned intensity of the fragments was selected.

\section{Statistical analyses}

The effect of the degree of hydrolysis and peptide length was tested with IBM SPSS version 23 using one-way ANOVA by performing the Tukey post hoc test. Differences were considered statistically significant at $p<0.001$. This was chosen because the comparison was always conducted on technical replicates.

\section{Results \& discussion}

\section{Levels of furosine and $\mathrm{BL}$ in the infant formulas}

Quantities of $N \varepsilon$-(2-furoylmethyl)-L-lysine (furosine) and the calculated BL level in the powdered infant formulas are shown in Table 1.

The levels of furosine ranged between 308 and $2022 \mathrm{mg}$ per $100 \mathrm{~g}$ protein, resulting in a range of 6.5 to $44.5 \% \mathrm{BL}$. These findings are in line with the expectation, as longer incubation of the products at elevated temperature is expected to cause an increased formation of MRPs. The relatively long incubation times needed to induce glycation can be explained by the low water activity in the powdered formula. The 6.5 to $20.8 \% \mathrm{BL}$ values are comparable to the infant formula values reported in the literature, while $44.5 \% \mathrm{BL}$ is a more extreme level. ${ }^{3}$
Table 1 Quantity of furosine and calculated blocked lysine (BL) levels of the different infant formula. BL percentages were derived from lysine and furosine levels measured after acid hydrolysis using ion-pair reversed-phase HPLC (Ansynth Service B.V., Breda, the Netherlands)

\begin{tabular}{lccc}
\hline $\begin{array}{l}\text { Heating } \\
\text { temperature }\left({ }^{\circ} \mathrm{C}\right)\end{array}$ & $\begin{array}{l}\text { Heating time } \\
\text { (hours) }\end{array}$ & $\begin{array}{l}\text { Furosine }[\mathrm{mg} \text { per } \\
100 \mathrm{~g} \text { protein }]\end{array}$ & $\begin{array}{l}\text { Lysine } \\
\text { blockage }\end{array}$ \\
\hline- & 0 & 308 & $6.5 \%$ \\
60 & 24 & 400 & $8.4 \%$ \\
60 & 72 & 556 & $11.8 \%$ \\
60 & 168 & 690 & $14.8 \%$ \\
60 & 288 & 977 & $20.8 \%$ \\
70 & 335 & 2022 & $44.5 \%$
\end{tabular}

\section{Protein hydrolysis}

Intact proteins were monitored using gel electrophoresis. Fig. 1 shows the SDS-gel images for all samples. All bands, but especially $\beta$-lactoglobulin and $\alpha$-lactalbumin, show a gradual shift with increasing glycation level, indicating an increase in the apparent molecular weight (MW). This is probably due to the sugars that bind to the milk proteins, increasing their MW. In addition, the $\alpha$-lactalbumin band broadens in the sample with $44.5 \%$ BL compared to the other samples and appears as a smear, indicating significant changes in $\alpha$-lactalbumin due to the glycation.

After 0.3 minutes in the GP, the casein band disappears in all samples, while two additional bands appear at MW 5 and $8 \mathrm{kDa}$. These bands represent large peptides formed during digestion, probably originating from caseins. $\beta$-Lactoglobulin and $\alpha$-lactalbumin, on the other hand, are not hydrolysed in the samples throughout the whole GP, independent of the glycation level.

In the IP, the intensity of intact $\beta$-lactoglobulin and $\alpha$-lactalbumin decreases after 5 minutes for all samples, with further slow decreases upon continued intestinal digestion. While both proteins disappear after 60 minutes in the IP in infant formula ranging from $6.5 \%$ to $14.9 \% \mathrm{BL}$, traces remain visible after 60 minutes in the IP for infant formula with $20.8 \%$ and $44.5 \%$ BL. After 120 minutes in the IP, all proteins are hydrolysed in all samples.

The rapid disappearance of casein in the GP and the relatively higher resistance of whey proteins to pepsin hydrolysis is in line with previous findings. ${ }^{28,29}$ In the $20.8 \%$ and $44.5 \%$ samples, some intact $\beta$-lactoglobulin is still present after 60 minutes in the IP. This is in line with a study by Corzo-Martínez et al., ${ }^{11}$ where $\beta$-lactoglobulin is more resistant after 15 minutes of intestinal hydrolysis when heated in the presence of sugars.

The degree of hydrolysis during infant in vitro digestion is shown in Table 2. Until 45 minutes in the GP, DH increases moderately in all samples. After 60 minutes in the GP, the infant formula with $8.4 \% \mathrm{BL}$ shows significantly higher $\mathrm{DH}$ than the other samples. However, the same tendency is not observed at the start of the IP and is also not reflected in the peptide analysis.

The largest increase in $\mathrm{DH}$ is observed from 60 minutes in the GP to the beginning of the IP (Table 2). In the first 


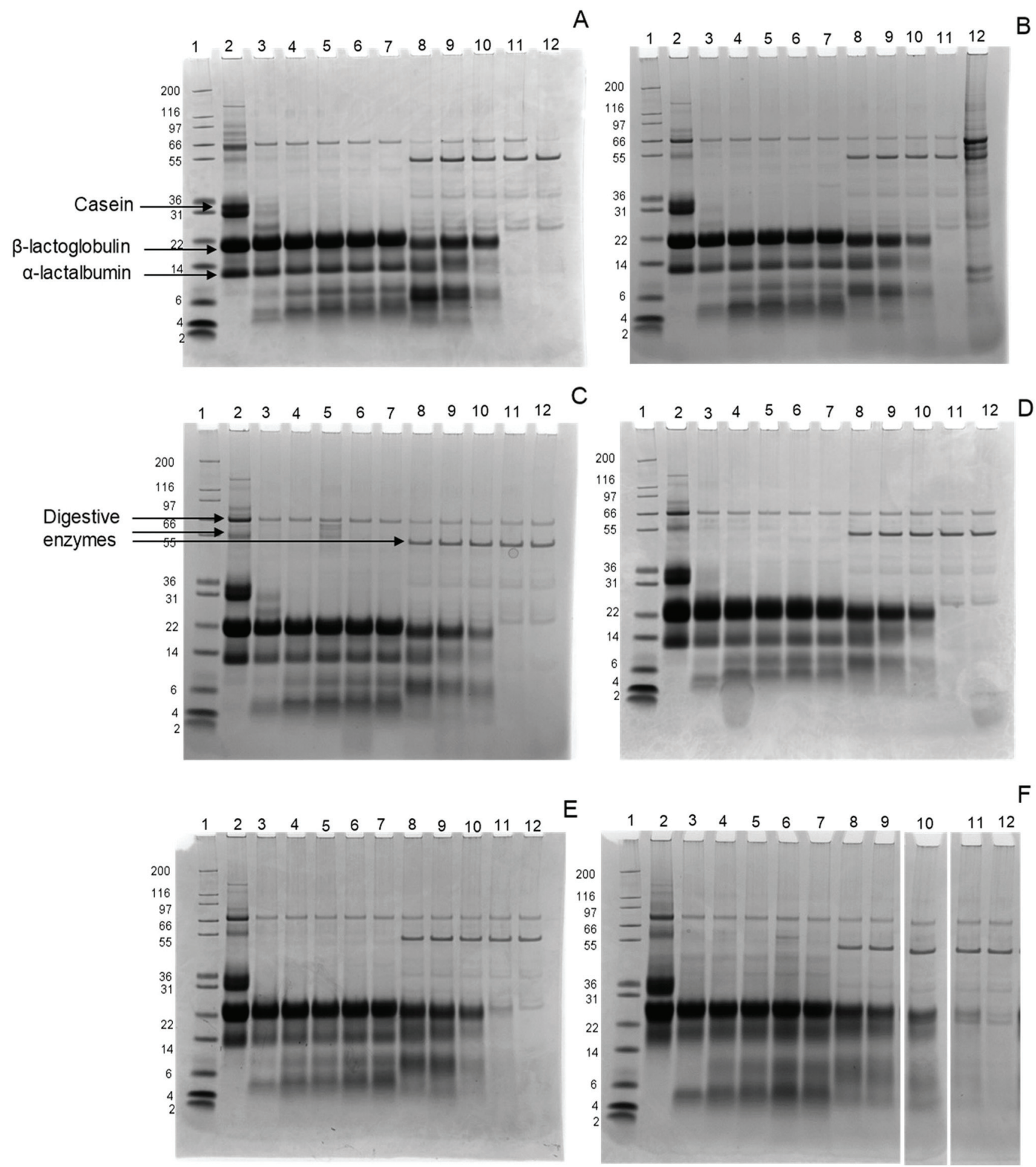

Fig. 1 SDS-PAGE images of infant formula with 6 levels of blocked lysine (BL) at various time points from the gastric phase (GP) and the intestinal phase (IP) of simulated infant in vitro digestion (A) sample $6.5 \%$ lysine blockage, (B) sample $8.4 \%$ lysine blockage, (C) sample $11.8 \%$ lysine blockage, (D) sample $14.9 \%$ lysine blockage, (E) sample $20.8 \%$ lysine blockage, and (F) sample $44.5 \%$ lysine blockage. Lane 1: Mark12 MW size marker, lane 2: non digested sample, lane 3: 0.3 minutes GP, lane 4: 15 minutes GP, lane 5: 30 minutes GP, lane 6: 45 minutes GP, lane 7: 60 minutes GP, lane 8: 5 minutes IP, lane 9: 15 minutes IP, lane 10: 30 minutes IP, lane 11: 60 minutes IP, lane 12: 120 minutes IP. 
Table 2 Degree of hydrolysis of infant formula with 6 different levels of blocked lysine (BL) at various time points during simulated infant in vitro digestion in the gastric phase (GP) and intestinal phase (IP). Data are expressed as mean of technical replicates \pm SD $(n=3)$. Letters indicate significant differences $(p<0.001)$

\begin{tabular}{|c|c|c|c|c|c|c|}
\hline \multicolumn{7}{|c|}{ Degree of hydrolysis [\%] } \\
\hline Sampling time point & $6.5 \% \mathrm{BL}$ & $8.4 \% \mathrm{BL}$ & $11.8 \% \mathrm{BL}$ & $14.8 \% \mathrm{BL}$ & $20.8 \% \mathrm{BL}$ & $44.5 \% \mathrm{BL}$ \\
\hline GP0 & $0.7 \pm 0.1 \mathrm{~ns}$ & $0.7 \pm 0.0 \mathrm{~ns}$ & $0.5 \pm 0.1 \mathrm{~ns}$ & $0.7 \pm 0.1 \mathrm{~ns}$ & $1.0 \pm 0.2 \mathrm{~ns}$ & $0.9 \pm 0.1 \mathrm{~ns}$ \\
\hline GP15 & $1.6 \pm 0.1 \mathrm{~ns}$ & $1.7 \pm 0.2 \mathrm{~ns}$ & $1.2 \pm 0.1 \mathrm{~ns}$ & $1.6 \pm 0.1 \mathrm{~ns}$ & $1.7 \pm 0.2 \mathrm{~ns}$ & $1.6 \pm 0.1 \mathrm{~ns}$ \\
\hline GP30 & $2.0 \pm 0.1 \mathrm{~ns}$ & $2.1 \pm 0.0 \mathrm{~ns}$ & $1.7 \pm 0.1 \mathrm{~ns}$ & $2.0 \pm 0.1 \mathrm{~ns}$ & $2.0 \pm 0.3 \mathrm{~ns}$ & $1.9 \pm 0.1 \mathrm{~ns}$ \\
\hline GP45 & $2.3 \pm 0.1 \mathrm{~ns}$ & $2.4 \pm 0.1 \mathrm{~ns}$ & $1.9 \pm 0.2 \mathrm{~ns}$ & $2.3 \pm 0.2 \mathrm{~ns}$ & $2.5 \pm 0.3 \mathrm{~ns}$ & $2.2 \pm 0.1 \mathrm{~ns}$ \\
\hline GP60 & $5.9 \pm 0.4 \mathrm{a}$ & $8.3 \pm 0.1 \mathrm{c}$ & $4.9 \pm 0.2 \mathrm{ab}$ & $5.7 \pm 0.2 \mathrm{a}$ & $5.9 \pm 0.3 \mathrm{a}$ & $4.3 \pm 0.2 \mathrm{~b}$ \\
\hline IP0.3 & $16.5 \pm 0.5 \mathrm{ac}$ & $14.4 \pm 0.5 \mathrm{ab}$ & $14.3 \pm 0.8 \mathrm{ab}$ & $13.6 \pm 0.4 \mathrm{~b}$ & $17.3 \pm 0.2 \mathrm{c}$ & $16.0 \pm 0.6 \mathrm{abc}$ \\
\hline IP1.0 & $15.8 \pm 0.5 \mathrm{a}$ & $14.6 \pm 0.13 \mathrm{abc}$ & $14.0 \pm 0.1 \mathrm{bc}$ & $13.5 \pm 0.3 b$ & $17.7 \pm 0.4 \mathrm{~d}$ & $15.5 \pm 0.2 \mathrm{ac}$ \\
\hline IP3.0 & $18.3 \pm 1.0 \mathrm{a}$ & $16.3 \pm 0.4 \mathrm{ab}$ & $15.6 \pm 0.5 \mathrm{ab}$ & $15.0 \pm 0.5 \mathrm{~b}$ & $18.2 \pm 0.5 \mathrm{a}$ & $16.1 \pm 0.8 \mathrm{ab}$ \\
\hline IP5.0 & $18.7 \pm 0.9 \mathrm{~ns}$ & $18.6 \pm 0.3 \mathrm{~ns}$ & $16.0 \pm 0.5 \mathrm{~ns}$ & $15.9 \pm 0.5 \mathrm{~ns}$ & $17.2 \pm 1.2 \mathrm{~ns}$ & $17.4 \pm 1.2 \mathrm{~ns}$ \\
\hline IP10 & $21.2 \pm 1.1 \mathrm{~ns}$ & $20.8 \pm 0.3 \mathrm{~ns}$ & $18.3 \pm 0.4 \mathrm{~ns}$ & $18.0 \pm 0.7 \mathrm{~ns}$ & $19.5 \pm 0.4 \mathrm{~ns}$ & $18.3 \pm 1.2 \mathrm{~ns}$ \\
\hline IP15 & $30.9 \pm 0.7 \mathrm{a}$ & $21.2 \pm 0.7 \mathrm{~b}$ & $19.8 \pm 0.1 \mathrm{~b}$ & $20.0 \pm 0.6 \mathrm{~b}$ & $21.9 \pm 1.4 \mathrm{~b}$ & $20.4 \pm 0.9 \mathrm{~b}$ \\
\hline IP30 & $35.5 \pm 1.4 \mathrm{a}$ & $24.1 \pm 1.3 \mathrm{~b}$ & $24.9 \pm 0.1 b$ & $23.7 \pm 0.6 b$ & $23.8 \pm 1.1 b$ & $23.3 \pm 0.8 \mathrm{~b}$ \\
\hline IP60 & $41.4 \pm 1.8 \mathrm{a}$ & $29.9 \pm 2.0 \mathrm{~b}$ & $28.8 \pm 1.2 \mathrm{~b}$ & $28.3 \pm 0.8 \mathrm{~b}$ & $30.7 \pm 1.2 \mathrm{~b}$ & $26.4 \pm 1.1 \mathrm{~b}$ \\
\hline IP120 & $46.8 \pm 3.9 \mathrm{a}$ & $32.8 \pm 1.2 \mathrm{~b}$ & $32.1 \pm 0.3 b$ & $33.7 \pm 0.6 b$ & $33.6 \pm 1.3 \mathrm{~b}$ & $29.8 \pm 0.8 b$ \\
\hline
\end{tabular}

10 minutes of the IP the DH of hydrolysis is moderate in all samples. Between 10 and 15 minute of the IP, a 32\% increased $\mathrm{DH}$ is observed in the infant formula with the lowest BL while the other samples show a gradual increase in the DH (Table 2). At the lowest level of $\mathrm{BL}, \mathrm{DH}$ is significantly higher than in the other infant formulas after 10 minutes of intestinal digestion onwards. No difference in the $\mathrm{DH}$ is observed between the other samples throughout the whole IP (Table 2). This indicates that gastric in vitro digestion of the infant formula is only affected to a limited extent by increasing levels of BL while intestinal in vitro digestion was already impaired from the lowest increase of $6.5 \%$ to $8.4 \% \mathrm{BL}$.

The results show a DH between $29.8 \pm 0.8 \%$ and $46.8 \pm$ $3.9 \%$ after complete infant in vitro digestion. Cattaneo et al. ${ }^{19}$ compared non-heated versus heated liquid infant formula model systems and measured peptides with a molecular weight below $3 \mathrm{kDa}$ to assess protein breakdown. A protein breakdown percentage between 35 and 54\% was reported after 120 minutes in the IP during infant in vitro digestion. This is in line with the DH after 120 minutes in the IP found in our study (Table 2). Interestingly, our results show a DH that is still increasing until 120 minutes in the IP. This suggests that protein hydrolysis was not complete yet, which could possibly be explained by the lower enzyme concentrations in the infant digestive tract.

In our study, only the $6.5 \%$ BL sample shows an increased protein hydrolysis compared to all other samples (Table 2). This suggests that an initial Maillard reaction, for example during storage, could already decrease protein hydrolysis. With the exception of the $6.5 \% \mathrm{BL}$ sample, $\mathrm{DH}$ was $7 \%$ lower for $44.5 \%$ BL after 60 and 120 minutes in the IP compared to the other IFs, although this was not significant. Nevertheless, this is in line with the SDS-PAGE results, where some $\beta$-lactoglobulin was still intact after 60 and 120 minutes in the IP for the $44.5 \%$ BL sample (Fig. 1). A possible explanation for not observing significant differences in $\mathrm{DH}$ compared to SDS-PAGE results could be that intact proteins are excluded from OPA analysis by TCA precipitation during sample preparation. Another reason could be that the proteins in the $6.5 \%$ BL may be cleaved to smaller peptides compared with the other samples. This is not visible on the gels, because only the breakdown of the intact proteins is visible.

In summary, the results suggest that the hydrolysis of $\beta$-lactoglobulin is affected, by showing an increased resistance of intact $\beta$-lactoglobulin to hydrolysis in the $20.8 \%$ and $44.5 \%$ BL samples. Overall protein hydrolysis was increased for the $6.5 \%$ BL sample.

\section{Peptide formation and average peptide length}

Peptides after 60 minutes of the GP and 60 minutes of the IP were analysed to monitor the effect of lysine blockage on peptide formation. In both GP and IP, fewer whey proteinderived peptides compared to casein-derived peptides were found. In the GP, the average response for whey protein- and casein-derived peptides was $2.5 \pm 0.12$ and $97.5 \pm 0.12 \%$ of the total response. In the IP samples, the average response for whey protein- and casein-derived peptides was $3.9 \pm 0.19$ and $96.1 \pm 0.19 \%$.

The low abundance of whey protein-derived peptides in the GP is in line with the SDS-PAGE data (Fig. 1), which indicates that whey protein hydrolysis in the GP is limited, consequently resulting in a lower number of whey protein-derived peptides. Similar observations were also made by Hodgkinson et al., ${ }^{30}$ who found no peptides derived from $\alpha$-lactalbumin and a maximum of $1.2 \%$ of the total number of peptides derived from $\beta$-lactoglobulin after 60 minutes in the GP using a simulated infant in vitro digestion model.

In an in vivo study in pigs, peptides were identified in duodenal effluents by LC-MS/MS after ingestion of six different dairy matrices. For raw milk, $14 \%$ of the identified peptides were derived from $\beta$-lactoglobulin, while $86 \%$ were derived from casein. ${ }^{31}$ It was suggested that the regions where only a few peptides were identified correspond to the regions that were hydrolysed to peptides smaller than 6 amino acids or to 
the regions that contained posttranslational modifications or disulphide bonds. Egger et $a .^{32}$ compared in vivo peptide release in piglets with in vitro data and found a relatively higher abundance of casein derived peptides compared to whey derived peptides in vivo and in vitro. An in vitro study by Sanchón et al. ${ }^{29}$ showed fewer whey protein-derived peptides than casein-derived peptides after adult in vitro digestion of casein or whey protein, but the difference was less than that observed in our study. Nevertheless, they indicated that the number of whey protein-derived peptides decreased with prolonged intestinal digestion. Moreover, it was reported that heat treatment affects the globular structure of whey proteins and the clot formation in the stomach. Both may result in a slower digestion of caseins compared to whey proteins. ${ }^{33,34}$ In line with this, Picariello et $a l^{35}$ reported that traces of $\beta$-lactoglobulin and $\alpha$-lactalbumin survive simulated gastrointestinal digestion; however, they stated that there is a high degree of protein hydrolysis based on the protein sequence recovery. It has thus repeatedly been observed in both animal and in vitro studies that the number of whey protein-derived peptides is lower than the number of casein-derived peptides. However, the comparison of different studies also suggests that the ratio of whey protein-derived peptides to caseinderived peptides strongly depends on the thermal history of the protein and the digestion conditions. For our results, we hypothesized that the hydrolysis of whey proteins in the GP is limited, while once in the IP, whey proteins are rapidly digested to such small peptides and free AAs that they can't be detected after 60 minutes in the IP anymore, or they are still too large to be detected.

After 60 minutes of the GP, the average peptide length was higher for the infant formula with $44.5 \%$ BL compared to $6.5 \% \mathrm{BL}$, but was not significantly higher compared to the other infant formulas (Fig. 2). This is in line with the OPAassay and SDS-PAGE that did not show any differences in the GP between the different BL levels (Fig. 1 and Table 2). After 60 minutes of the IP, the average peptide length of the sample with $44.5 \%$ BL was significantly higher with longer peptides with 1.2 AAs on average compared to all other samples. Recently, Komatsu et $a .^{36}$ used the molecular weight distribution of peptides to assess casein digestibility after in vitro gastrointestinal digestion. To our knowledge, our study is the first that used peptide length distribution to directly present results on the extent of protein hydrolysis. This approach shows differences in protein hydrolysis in much more detail than possible with the OPA-assay. Differences in the GP were small compared to the difference shown in the IP. In contrast to the OPA-assay, peptides smaller than 5 amino acids and free amino acids are not included in the peptidomics approach, and therefore the average peptide length will be overestimated, especially in the intestinal phase. Nevertheless, comparison between the samples is possible.

The results were in line with in vitro studies that showed a decreased hydrolysis of milk proteins when glycated. ${ }^{8,9,11-13}$ The effect can be explained by the higher glycation level limiting hydrolysis by trypsin, which cleaves specifically after arginine and lysine residues. ${ }^{37}$ Deng et al. ${ }^{16}$ showed that glycation of lysine residues inhibits tryptic protein hydrolysis of $\alpha$-lactalbumin. In addition, glycation of lysine within the docking area of an enzyme can prevent the enzyme from cleavage, thereby limiting hydrolysis. While the focus in this study was on Maillard-induced BL, other heat-induced modifications, e.g. oxidation, could have influenced the results as well. An example would be the formation of disulphide bonds between cysteine residues. This can lead to cross linking of amino acid side chains and might thereby result in reduced accessibility of the protein to the digestive enzymes. The formation of disulphide bonds is promoted by the presence of reducing sugars and low water activity during the heating process. ${ }^{38,39}$

\section{Peptide size distribution}

To construct a peptide size distribution plot, peptides were grouped based on their number of AAs. Relative abundance
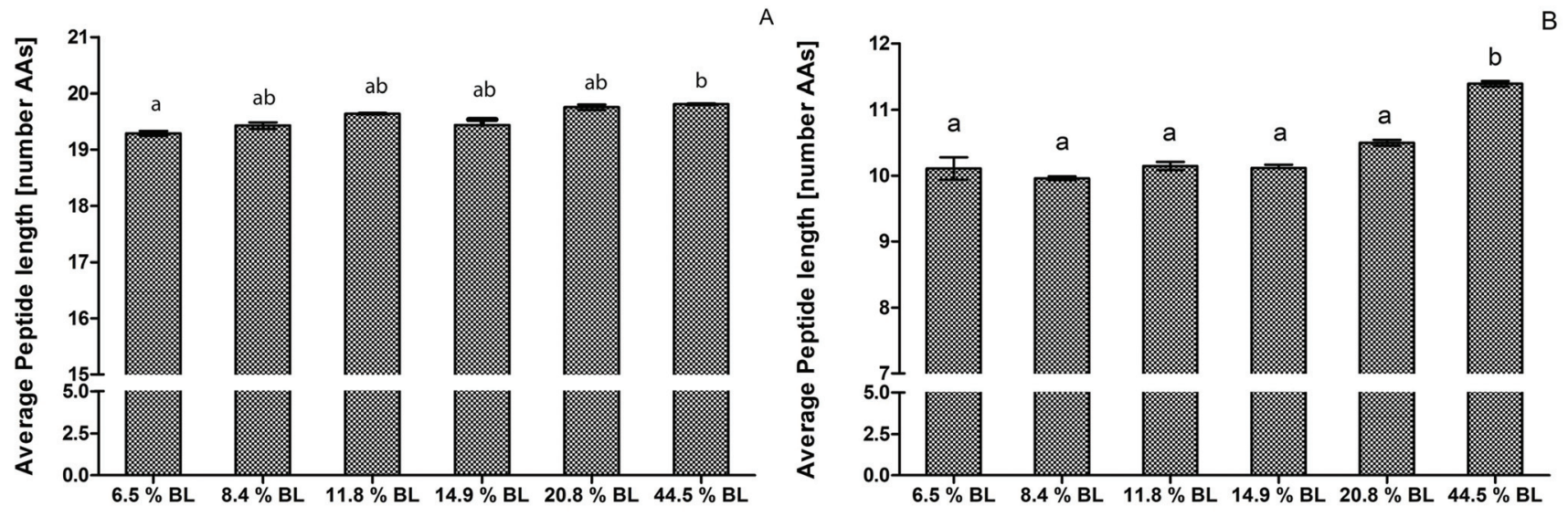

Fig. 2 Average peptide length by number of AA residues after simulated infant digestion of infant formula with various levels of blocked lysine (BL). Average peptide length after 60 minutes in the gastric phase. (B) Average peptide length after 60 minutes in the intestinal phase. Letters indicate significant differences of technical duplicates $(p<0.001)$. 


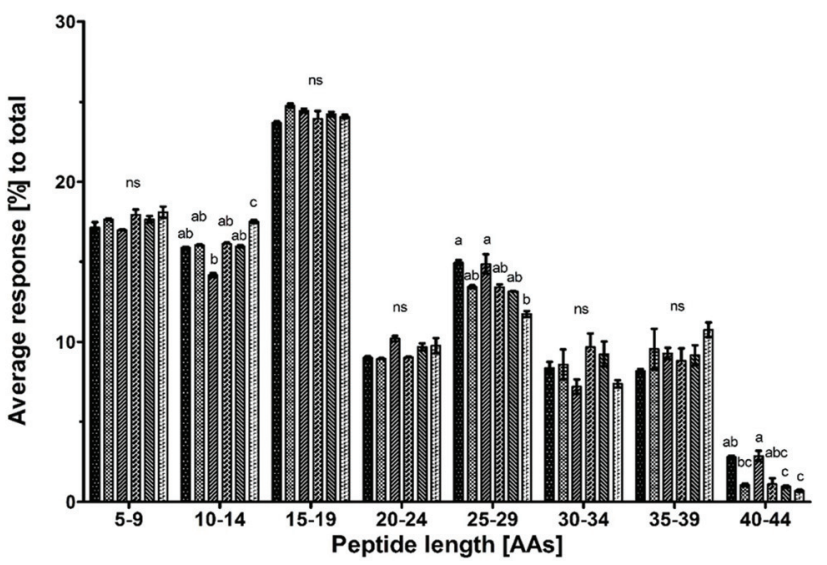

.

was expressed as the percentage response of the peptides in each size range to the total response of peptides in the sample (Fig. 3). Peptides with 15-19 AAs were the most abundant in all GP samples. A trend towards a decreasing percentage with increasing glycation level was observed in the size range of 25-29 AAs. However, this decrease was not accompanied by a glycation level dependent increase in another size range. Additionally, average peptide length after 60 minutes in the GP was increased in $44.5 \%$ BL samples compared to the sample with $6.5 \% \mathrm{BL}$, but not compared to the other samples. Therefore, it can be concluded that there is no effect of glycation on peptide size distribution after gastric hydrolysis (Fig. 3a).

After 60 minutes in the IP, the average response of the sample with $44.5 \%$ BL was higher in the size ranges of 15-19, 25-29, and 30-34 AAs compared to all other samples. At the same time, the average response of the smallest peptide size range of 5-9 AAs was $10 \%$ lower than that in the infant formulas with the lowest level of BL. A significant decrease of the peptides with 5-9 AAs was also observed for the infant formula with $20.8 \%$ BL compared to infant formula between 8.4 and $14.9 \% \mathrm{BL}$. A trend towards increasing responses of the peptides in larger size ranges (10-14 and 15-19 AAs) was observed for this sample as well, but this was not significantly different compared to all other samples (Fig. 3b). Taken together, this indicates that glycation reduces the breakdown of larger peptides to smaller peptides in the IP at glycation levels of 20.8 and $44.5 \%$ BL.

Peptide size distribution after 60 minutes in the IP for casein-derived and whey protein-derived peptides separately are shown in Fig. 4. Whey protein-derived peptides ranged in length between 5 and 24 AAs, with most peptides in the size range 5-9 AAs. However, no differences between the samples were observed in any size range. The limited response, and the low average length, of whey protein-derived peptides compared to casein-derived peptides is in line with the suggestion discussed earlier that whey proteins are probably quickly hydrolysed to peptides smaller than 5 AAs at the start of the IP, thus leading to a low percentage of whey protein-derived peptides after 60 minutes in the IP. 

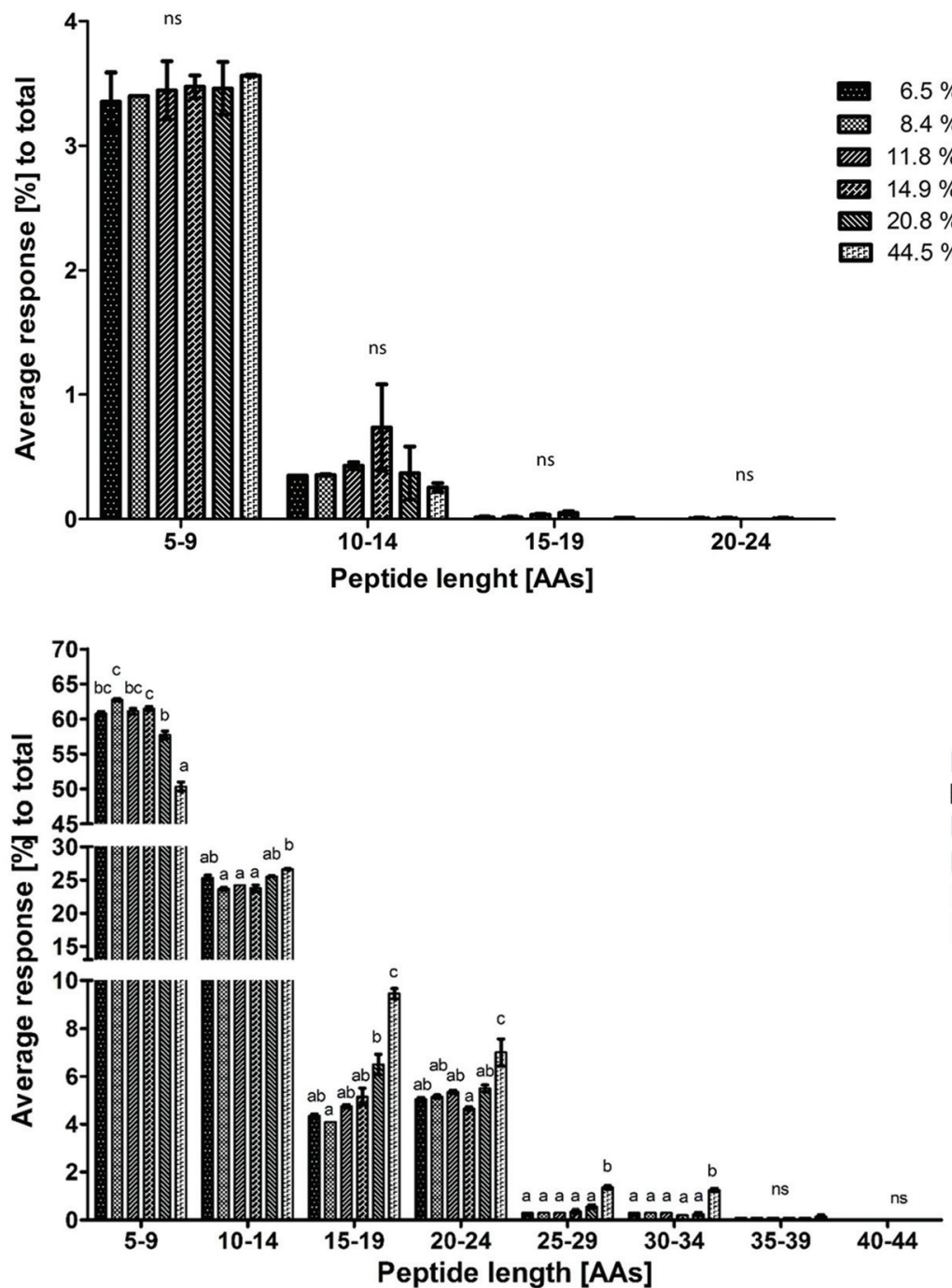

B

Fig. 4 Average peptide response for technical duplicate in percentage for each size range to the total peptide response after 60 minutes in the intestinal phase. Peptides were divided in whey protein-derived peptides (A) and casein-derived peptides (B). Infant formula with 6 different levels of blocked lysine $(\mathrm{BL})$ was compared with each other. Error bars represent the standard deviation of technical duplicates. Letters indicate statistical differences $(p<0.001)$ between samples within one size range, while 'ns' indicates no significant differences.

Because the intensity of whey protein-derived peptides was limited, the peptide size distribution of casein-derived peptides is almost identical to the total peptide size distribution. Peptide release from casein changed towards larger peptides, showing a trend for $20.8 \%$ BL and a significant effect at $44.5 \% \mathrm{BL}$.

To our knowledge, this is the first study that used a peptide length distribution to assess digestibility. The decreased digestibility of casein is in line with the literature on sodium caseinate. Hiller et $a l .{ }^{17}$ showed a decreased release of soluble nitrogen after pancreatic in vitro digestion for sodium caseinate heated with lactose, pectin or dextran. In another study, Culver $e a^{8}{ }^{8}$ showed a loss in the digestibility for sodium caseinate heated with glucose. Both studies used the OPA analysis to assess the formation of smaller peptides. Together with our results on peptide formation, this suggests a major effect of glycation up to 20.8 and $44.5 \%$ BL on casein hydrolysis in the reduced breakdown of larger peptides into smaller peptides.

Data analysis on single caseins after 60 minutes in the IP showed an increasing average peptide length for all caseins in the highest glycated infant formula compared to the lowest glycated infant formula (Table 3). The largest difference was observed for $\alpha_{\mathrm{s} 1}$-casein and $\alpha_{\mathrm{s} 2}$-casein with increasing average peptide length of 1.6 AAs. This was followed by $\kappa$-casein and $\beta$-casein with an average increase by 1.1 AAs and 0.9 AAs, respectively. Furthermore, the number of identified peptides relatively increased with an increase in the glycation level (data not shown). This is in line with the increase in the average peptide length with a higher glycation level. A reduced hydrolysis is expected to increase the number of peptides identified, 
Table 3 Average peptide length of $\alpha_{\mathrm{s} 1}$-casein, $\alpha_{\mathrm{s} 2}$-casein, $\beta$-casein, and $\kappa$-casein after 60 minutes in the intestinal phase. Infant formula with 6 different levels of blocked lysine (BL) was compared with each other. Letters indicate statistical differences $(p<0.001)$ between technical duplicates

\begin{tabular}{|c|c|c|c|c|c|c|}
\hline Protein/sample & $6.5 \% \mathrm{BL}$ & $8.4 \% \mathrm{BL}$ & $11.8 \% \mathrm{BL}$ & $14.9 \% \mathrm{BL}$ & $20.8 \% \mathrm{BL}$ & $44.5 \% \mathrm{BL}$ \\
\hline$\alpha_{\mathrm{s} 2}$-Casein & $11.2 \pm 0.24 \mathrm{a}$ & $10.9 \pm 0.08 \mathrm{a}$ & $11.1 \pm 0.05 \mathrm{a}$ & $11.1 \pm 0.03 \mathrm{a}$ & $11.7 \pm 0.12 \mathrm{ab}$ & $12.7 \pm 0.03 \mathrm{~b}$ \\
\hline$\beta$-Casein & $9.6 \pm 0.10 \mathrm{a}$ & $9.5 \pm 0.05 \mathrm{a}$ & $9.5 \pm 0.12 \mathrm{a}$ & $9.7 \pm 0.03 \mathrm{a}$ & $10.0 \pm 0.07 \mathrm{ab}$ & $10.5 \pm 0.02 b$ \\
\hline$\kappa$-Casein & $9.4 \pm 0.09 \mathrm{a}$ & $9.4 \pm 0.13 \mathrm{a}$ & $9.9 \pm 0.08 \mathrm{ab}$ & $9.7 \pm 0.01 \mathrm{a}$ & $10.0 \pm 0.12 \mathrm{ab}$ & $10.5 \pm 0.01 \mathrm{~b}$ \\
\hline
\end{tabular}

because both the large glycated peptides and the smaller peptides derived from its hydrolysis can now be identified, while these large peptides will be fully hydrolysed when not glycated.

In all peptide length ranges at the highest level of $\mathrm{BL}, \alpha_{\mathrm{s} 1^{-}}$ casein and $\alpha_{\mathrm{s} 2}$-casein together contributed to over $50 \%$ of the peptides (data not shown). For $\alpha_{\mathrm{s}^{1}}$-casein this is probably because it is the major protein in the casein fraction. For $\alpha_{\mathrm{s} 2^{-}}$ casein it can be explained by its impaired digestibility as was also shown previously. ${ }^{40}$ Especially in the size ranges of $20-24$ AAs and 25-29 AAs, the relative number of $\alpha_{\mathrm{s} 2}$-casein derived peptides increased from $35 \%$ to $42 \%$ and $17 \%$ to $32 \%$ of total peptides compared to the infant formula with the lowest BL level, whereas for $\kappa$-casein an increase in the 30-34 AA range was found from $2 \%$ to $8 \%$ of total peptides (data not shown). Dupont et al. ${ }^{41}$ showed that the large fragments visible on the SDS-PAGE after in vitro digestion of the processed infant formula originate from $\alpha_{\mathrm{s} 2}$-casein and $\kappa$-casein. This also resulted in high residual immunogenicity of specific $\alpha_{\mathrm{s} 2}$-casein regions compared to undigested infant formula. Although, these results can't be directly compared to our findings, because of the different methodologies, both studies show that casein digestion is affected by its glycation, leading to larger peptides. The survival of such larger peptides during gastrointestinal digestion can also lead to increased residual immunogenicity. It has to be noted that the residual immune reactivity after infant in vitro digestion was not measured in this study. Nevertheless, the finding that a high level of BL in infant formula resulted in longer peptides could lead to survival of immunogenic peptides after in vitro gastrointestinal digestion.

\section{Conclusion}

To our knowledge, this is the first study that investigates the effect of BL on the protein hydrolysis of powdered infant formula with different levels of BL. The results suggest that infant formula with a BL level up to $44.5 \%$, and to a lesser extent $20.8 \%$, show a decreased digestibility. Hydrolysis of whey proteins is mainly affected by an increased resistance to digestion for intact $\beta$-lactoglobulin. Casein hydrolysis is mainly affected by an impaired formation of peptides smaller than 15 AAs with an increased level of BL. Small differences in BL within the $6.4 \%$ to $14.9 \%$ range did not result in changes in digestibility.

The decreased digestibility of infant formula due to BL impairs its protein quality and may have physiological conse- quences for infants. However, the effect of increased BL levels in infant formula on protein digestibility is dependent on the final level of BL and may be limited in commercial products. Nevertheless, mild processing of milk proteins is warranted to maintain nutritional quality. Further research on the possible physiological consequences for infants is needed.

\section{Conflicts of interest}

GAAvL, MPvG and MCEB are employees of FrieslandCampina. The study was sponsored by FrieslandCampina.

\section{Acknowledgements}

We thank Christel J. A. M. Timmer-Keetels for critically reviewing the manuscript.

\section{Notes and references}

1 M. A. J. S. Van Boekel, Effect of heating on Maillard reactions in milk, Food Chem., 1998, 62, 403-414.

2 H. F. Erbersdobler and V. Somoza, Forty years of furosine Forty years of using Maillard reaction products as indicators of the nutritional quality of foods, Mol. Nutr. Food Res., 2007, 51, 423-430.

3 B. M. Mehta and H. C. Deeth, Blocked Lysine in Dairy Products: Formation, Occurrence, Analysis, and Nutritional Implications, Compr. Rev. Food Sci. Food Saf., 2016, 15, 206218.

4 G. A. A. van Lieshout, T. T. Lambers, M. C. E. Bragt and K. A. Hettinga, How processing may affect milk protein digestion and overall physiological outcomes: A systematic review, Crit. Rev. Food Sci. Nutr., 2019, 22, 1-24.

5 P. J. Moughan and S. M. Rutherfurd, A New Method for Determining Digestible Reactive Lysine in Foods, J. Agric. Food Chem., 1996, 44, 2202-2209.

6 S. M. Rutherfurd and P. J. Moughan, Application of a New Method for Determining Digestible Reactive Lysine to Variably Heated Protein Sources, J. Agric. Food Chem., 1997, 45, 1582-1586.

7 A. Rérat, R. Calmes, P. Vaissade and P. A. Finot, Nutritional and metabolic consequences of the early Maillard reaction 
of heat treated milk in the pig. Significance for man, Eur. J. Nutr., 2002, 41, 1-11.

8 C. A. Culver and H. E. Swaisgood, Changes in the Digestibility of Dried Casein and Glucose Mixtures Occurring During Storage at Different Temperatures and Water Activities, J. Dairy Sci., 1989, 72, 2916-2920.

9 T. Desrosiers, L. Savoie, G. Bergeron and G. Parent, Estimation of Lysine Damage in Heated Whey Proteins by Furosine Determinations in Conjunction with the Digestion Cell Technique, J. Agric. Food Chem., 1989, 37, 1385-1391.

10 M. L. Sanz, M. Corzo-Martínez, R. A. Rastall, A. Olano and F. J. Moreno, Characterization and in vitro digestibility of bovine $\beta$-lactoglobulin glycated with galactooligosaccharides, J. Agric. Food Chem., 2007, 55, 7916-7925.

11 M. Corzo-Martínez, A. C. Soria, J. Belloque, M. Villamiel and F. J. Moreno, Effect of glycation on the gastrointestinal digestibility and immunoreactivity of bovine $\beta$-lactoglobulin, Int. Dairy J., 2010, 20, 742-752.

12 M. S. Pinto, J. Léonil, G. Henry, C. Cauty, A. F. Carvalho and S. Bouhallab, Heating and glycation of $\beta$-lactoglobulin and $\beta$-casein: Aggregation and in vitro digestion, Food Res. Int., 2014, 55, 70-76.

13 Y. Joubran, A. Moscovici, R. Portmann and U. Lesmes, Implications of the Maillard reaction on bovine alpha-lactalbumin and its proteolysis during in vitro infant digestion, Food Funct., 2017, 8, 2295-2308.

14 T. Desrosiers and L. Savoie, Extent of damage to amino acid availability of whey protein heated with sugar, J. Dairy Res., 1991, 58, 431-441.

15 M. Corzo-Martínez, M. Ávila, F. J. Moreno, T. Requena and M. Villamiel, Effect of milk protein glycation and gastrointestinal digestion on the growth of bifidobacteria and lactic acid bacteria, Int. J. Food Microbiol., 2012, 153, 420-427.

16 Y. Deng, P. A. Wierenga, H. A. Schols, S. Sforza and H. Gruppen, Effect of Maillard induced glycation on protein hydrolysis by lysine/arginine and non-lysine/arginine specific proteases, Food Hydrocolloids, 2017, 69, 210-219.

17 B. Hiller and P. C. Lorenzen, Functional properties of milk proteins as affected by Maillard reaction induced oligomerisation, Food Res. Int., 2010, 43, 1155-1166.

18 Y. Joubran, A. Moscovici and U. Lesmes, Antioxidant activity of bovine alpha lactalbumin Maillard products and evaluation of their in vitro gastro-duodenal digestive proteolysis, Food Funct., 2015, 6, 1229-1240.

19 S. Cattaneo, M. Stuknytè, F. Masotti and I. De Noni, Protein breakdown and release of $\beta$-casomorphins during in vitro gastro-intestinal digestion of sterilised model systems of liquid infant formula, Food Chem., 2017, 217, 476-482.

20 Y. Wada and B. Lönnerdal, Effects of different industrial heating processes of milk on site-specific protein modifications and their relationship to in vitro and in vivo digestibility, J. Agric. Food Chem., 2014, 62, 4175-4185.

21 M. Pischetsrieder and T. Henle, Glycation products in infant formulas: Chemical, analytical and physiological aspects, Amino Acids, 2012, 42, 1111-1118.
22 EFSA Panel on Dietetic Products, Nutrition and Allergies, Scientific Opinion on the essential composition of infant and follow-on formulae, EFSA J., 2014, 12(7), 3760.

23 B. Sarriá, R. López-Fandiño and M. P. Vaquero, Protein nutritive utilization in rats fed powder and liquid infant formulas, Food Sci. Technol. Int., 2000, 6, 9-16.

24 S. Rudloff and B. Lönnerdal, Solubility and digestibility of milk proteins in infant formulas exposed to different heat treatments, J. Pediatr. Gastroenterol. Nutr., 1992, 15, 25-33.

25 O. Ménard, C. Bourlieu, S. C. De Oliveira, N. Dellarosa, L. Laghi, F. Carrière, F. Capozzi, D. Dupont and A. Deglaire, A first step towards a consensus static in vitro model for simulating full-term infant digestion, Food Chem., 2018, 240, 338-345.

26 T. Delgado, N. Corzo, G. Santa-María, M. L. Jimeno and A. Olano, Determination of furosine in milk samples by ion-pair reversed phase liquid chromatography, Chromatographia, 1992, 33, 374-376.

27 A. I. Mulet-Cabero, N. M. Rigby, A. Brodkorb and A. R. Mackie, Dairy food structures influence the rates of nutrient digestion through different in vitro gastric behaviour, Food Hydrocolloids, 2017, 67, 63-73.

28 M. R. Guo, P. F. Fox, A. Flynn and P. S. Kindstedt, Susceptibility of $\beta$-Lactoglobulin and Sodium Caseinate to Proteolysis by Pepsin and Trypsin, J. Dairy Sci., 1995, 78, 2336-2344.

29 J. Sanchón, S. Fernández-Tomé, B. Miralles, B. HernándezLedesma, D. Tomé, C. Gaudichon and I. Recio, Protein degradation and peptide release from milk proteins in human jejunum. Comparison with in vitro gastrointestinal simulation, Food Chem., 2018, 239, 486-494.

30 A. J. Hodgkinson, O. A. M. Wallace, G. Smolenski and C. G. Prosser, Gastric digestion of cow and goat milk: Peptides derived from simulated conditions of infant digestion, Food Chem., 2019, 276, 619-625.

31 F. Barbé, S. Le Feunteun, D. Rémond, O. Ménard, J. Jardin, G. Henry, B. Laroche and D. Dupont, Tracking the in vivo release of bioactive peptides in the gut during digestion: Mass spectrometry peptidomic characterization of effluents collected in the gut of dairy matrix fed mini-pigs, Food Res. Int. , 2014, 63, 147-156.

32 L. Egger, O. Ménard, C. Baumann, D. Duerr, P. Schlegel, P. Stoll, G. Vergères, D. Dupont and R. Portmann, Digestion of milk proteins: Comparing static and dynamic in vitro digestion systems with in vivo data, Food Res. Int., 2019, 118, 32-39.

33 L. Rinaldi, S. F. Gauthier, M. Britten and S. L. Turgeon, In vitro gastrointestinal digestion of liquid and semi-liquid dairy matrixes, LWT-Food Sci. Technol., 2014, 57, 99-105.

34 A. Ye, J. Cui, D. Dalgleish and H. Singh, Formation of a structured clot during the gastric digestion of milk: Impact on the rate of protein hydrolysis, Food Hydrocolloids, 2016, 52, 478-486.

35 G. Picariello, P. Ferranti, O. Fierro, G. Mamone, S. Caira, A. Di Luccia, S. Monica and F. Addeo, Peptides surviving the simulated gastrointestinal digestion of milk proteins: 
Biological and toxicological implications, J. Chromatogr. B: Anal. Technol. Biomed. Life Sci., 2010, 878, 295-308.

36 Y. Komatsu, Y. Wada, H. Izumi, T. Shimizu, Y. Takeda, T. Hira and H. Hara, Casein materials show different digestion patterns using an in vitro gastrointestinal model and different release of glucagon-like peptide- 1 by enteroendocrine GLUTag cells, Food Chem., 2019, 277, 423-431.

37 J. V. Olsen, S. E. Ong and M. Mann, Trypsin cleaves exclusively C-terminal to arginine and lysine residues, Mol. Cell. Proteomics, 2004, 3, 608-614.

38 H. B. Cardoso, P. A. Wierenga, H. Gruppen and H. A. Schols, Maillard induced aggregation of individual milk proteins and interactions involved, Food Chem., 2019, 276, 652-661.
39 M. Gulzar, S. Bouhallab, J. Jardin, V. Briard-Bion and T. Croguennec, Structural consequences of dry heating on alpha-lactalbumin and beta-lactoglobulin at $\mathrm{pH}$ 6.5, Food Res. Int., 2013, 51, 899-906.

40 D. Dupont, G. Mandalari, D. Mollé, J. Jardin, O. RoletRépécaud, G. Duboz, J. Léonil, C. E. N. Mills and A. R. Mackie, Food processing increases casein resistance to simulated infant digestion, Mol. Nutr. Food Res., 2010, 54, 1677-1689.

41 D. Dupont, R. Boutrou, O. Menard, J. Jardin, G. Tanguy, P. Schuck, B. B. Haab and J. Leonil, Heat treatment of milk during powder manufacture increases casein resistance to simulated infant digestion, Food Dig., 2010, 1, 28-39. 